\title{
A Qualitative Study: Evaluation of Formation Education by Teacher Candidates, Mentor Teachers and Coordinators: An Example of Karabuk University/Turkey
}

\author{
Nurhayat Çelebi ${ }^{1}$, Ömer Aydoğdu ${ }^{2}$, Münevver Yalçınkaya ${ }^{3}$ \\ ${ }^{1}$ Karabuk University Faculty of Letters, Education Sciences Department, Turkey \\ ${ }^{2}$ Correspondence: Karabuk University Faculty of Letters, Education Sciences Department, Turkey \\ ${ }^{3}$ International Cyprus University, Faculty of Education, Education Sciences Department, Turkey \\ Correspondence: Nurhayat Çelebi, Karabuk University Faculty of Letters, Education Sciences Department, Turkey.
}

Received: December 3, 2017

doi:10.11114/jets.v6i3a.3166

\author{
Accepted: March 24, 2018 \\ Online Published: April 1, 2018 \\ URL: https://doi.org/10.11114/jets.v6i3a.3166
}

\begin{abstract}
The aim of this study was to learn the opinion of the teacher candidates who study pedagogical formation in Karabuk University in 2016-2017 teaching session, as well as mentor teachers and coordinators who lead them during the teaching practices at schools. This research study is mainly based on qualitative techniques. Working group of this study is composed of 155 teacher candidates, 56 mentor teachers and 16 coordinators. Three open-ended questions were given to the teacher candidates, mentors and coordinators for collection of data. The data were evaluated as in the mean of content analysis. According to the findings, teacher candidates expressed that "mentor teachers and coordinators at schools of implementation had a positive and supportive attitude towards them" while some of the candidates were expressing that "mentor teachers are not supportive." Mentor teachers and coordinators found teacher candidates' attitudes positive and refined. Mentor teachers and coordinators mentioned negative references about teacher candidates. They said that teacher candidates didn't use proper teaching methods, techniques and materials when the teacher candidates are teaching, and failed to manage and maintain classroom atmosphere and the intended lesson time. It is considerable that teacher candidates had also mentioned that "they were doing the same mistakes what their coordinators and teachers determined." As a result, teaching practice schedules should be well arranged in the way of cooperation between the University and the National Ministry of education, which was suggested to the authorities in the Turkish Higher Education Board.
\end{abstract}

Keywords: teacher candidates; mentor teachers; coordinators

\section{Introduction}

As our resources of knowledge increase speedily in this globalized world, it is essential that teachers have both capability and higher education to transfer knowledge to their students in a proper way. In the world, different countries have conducted different quests to chase a better solution of this problem. The missions has political dimensions, in addition to economic and social aspects. For their teacher training schedule, countries are working on new programmes and curricula that rely on constant improvement and advancements.

For this reason, almost all policy makers around the globe have placed teachers on the root of the reforms in their education system. Basically these reforms cover a set of arrangements such as training, employment, career development and professional improvement of teachers (Abazoğlu, 2014). To keep pace with such changes, teacher training process is altered continuously in our country.

Teaching entails reserves of knowledge, planning skills, field information, language skills, tendency to technological advancements, ability to make use of technological tools, and effective and efficient student counselling with different characteristics at different levels, (Gürlen and Demirel, 2010). It demonstrated with experimental research studies that teacher training schedules have a great influence on teacher candidate. In these schedules, teacher candidates acquire a general vision in learning and teaching issues. The teacher candidates become capable of integrating courses, practices and strategies, and combining relatively disconnected modules (Darling-Hammond., Hammerness, Grossman, Rust \& Shulman, 2005:292; Darling- Hammond, 2006). 
The education of teachers, before they start to actual service was given under control of the universities, which is conducted in collaboration with the Council of Higher Education (YÖK in Turkish) and Turkish Ministry of National Education in 1990.

In 1994, Faculty-School Collaboration Document was prepared within the scope of the project for teaching practices, and it was implemented into practice during July 1998 (Kavak, 1999 and Ministry of National Education, 1998).

Mainly changes based on the programme were made from 1997 till 2007. According to those changes, the graduates from the Faculty of Science and Letters were given the right of having pedagogical formation certificate. However, the BA and BSc diploma holders have to take the pedagogy education for one year more apart from their 4 year of university education. On the contrary, the graduates of the Education Faculties do not have to (Ministry of National Education, 2009). Those graduates of faculties have to get the teaching practice at schools either in the final year of their education or in the last semester of the certificate programme. While they are practising at schools mentor teachers' attitudes influence the teacher candidates more than what they teach them theoretically. Mentor teachers at school should share their experiences and knowledge about teaching with the teacher candidates. The last official changings on this point is to put more responsibilities on the school mentors and coordinators' shoulders than deliver the university coordinating lecturers. Therefore, the opinions of those two group teachers at schools have made the researchers' interest more. This study was performed to learn about the opinions of the teacher candidates who study pedagogical formation, as well as mentor teachers and coordinators who lead them during the teaching practices at school. Sub problems of this study are as followed:

1. What will happen when teacher candidates' positive attitude and behaviours encounter during practice at schools?

2. What will happen when teacher candidates' negative attitude and behaviours encounter during practice at schools?

3. What are the teacher candidates' challenges during teaching?

4. What are the mentor teachers' observing opinions about the teacher candidates attending to the teaching practice?

5. What are the coordinators' observing opinions about the teacher candidates attending to the teaching practice?

\section{Methods}

In this research study, we have used qualitative research method. It is a phenomenological research study focusing on phenomena that are known not profoundly (Yıldırım, Simsek, 2008).

\subsection{Participants and Procedure}

Target population of this study is composed of 402 teacher candidates that have enrolled for teaching formation at Karabuk University Faculty of Letters in the second terms of academic years 2016-2017. In addition, 70 and 19 mentor teachers and coordinators respectively. 155 teacher candidates, 56 mentor teachers and 16 coordinators took part in the study. 65 of the teacher candidates that took part in the study are female while 90 are male. 36 of the mentor teachers are female and the rest of 20 mentor teachers are male. 11 of the coordinators are male and 5 of them are female.

\subsection{Instrument and Data Collection}

As a data collection tool, every subject were given an individual question form composed of three open-ended questions. Literature review was performed and expert opinions were received for preparing questionnaire. Questions were mainly based on three themes including; 1 . Positive attitudes and behaviours of teacher candidates encounter during practice at schools; 2. Negative attitudes and behaviours of teacher candidates encounter during practice at schools; 3 . Challenges of teacher candidate encounter during teaching.

Common inquires given to mentor teachers and coordinators are as follows: "General attitudes and behaviours of the candidates, number and by designating the responding subject's gender. They are saved after received if needed. Hence, external confidence (Patton, 1987) is aimed by specifying that the result is coherent with the existing theoretical framework. Data were analyzed by using the methods of content analysis. Frequency is given next to main themes and sub themes on each table. Frequency analysis is important in that it reveals numerical, percental and proportional occurrence of units and elements. This is how internal confidence (Rubin and Rubin, 2005; Yıldırım and Şimşek, 2008) of the study is aimed.

\section{Data Analysis}

Data were analysed by using the methods of content analysis. Frequency is given next to main and sub themes on each table. Frequency analysis is important in that it reveals numerical, percental and proportional occurrence of units and elements. This is how internal confidence (Rubin ve Rubin, 2005; Yıldırım and Şimşek, 2008) of the study is aimed. Data collected from the study have been recorded in a computer-aided medium. The data have been compiled under given main themes. The main themes and the sub-themes have been designated considering similarity of the topics. 
Responses given by each subject were itemised without commenting. There are three to four sub-themes under each main theme. Each response given about the subjects has been recorded with a code. The codes used in this research are as follows: Teacher candidate (TC), mentor teacher $(M T)$, coordinator $(C)$, female $(F)$, man $(M)$.

\section{Findings}

In this part, responses received from the teacher candidate, mentor teacher and coordinators are classified under main themes and subthemes, and tables are prepared and finding comments are given.

Table 1. Teacher candidates positive attitudes and behaviours of during the teaching practice

\begin{tabular}{ll}
\hline Sub Themes & $\mathrm{f}$ \\
\hline Giving Support & \\
School administration and mentor teachers play a supportive role during internship period & 86 \\
Mentor teacher shows interest to teacher candidates, is well disciplined and exhibits good & 8 \\
behaviours & 6 \\
Mentor teacher shares clues and gives hints of teaching based on his/her experience & 4 \\
Good relationship between the principle and the staff & 2 \\
Mentor teacher acts as a guide in sorting out the problems of classroom management & 106 \\
Total & \\
Communication Skill & 16 \\
Student-teacher communication is good and friendly & 6 \\
Peer-to-peer communication with students in learning-teaching process & 6 \\
Establishing good relationships with students, giving them opportunity of learning through & \\
experience & 28 \\
Total & \\
Educational Environments & 8 \\
Classroom size is ideal for teaching and educational purposes & 6 \\
Technological equipment is good at school & 8 \\
There are smart boards in classrooms & 2 \\
The school provides al qualified teachers and advanced education & 2 \\
School and classrooms are clean & 26 \\
Total & \\
Education & 22 \\
Students listen to their teacher carefully in class, and proactively interact & 6 \\
The school applies inclusive education & 5 \\
Teachers help teacher candidates to make-up their deficiencies & \\
Mentor teacher prepares the lessons properly and presents it well & 2 \\
Teachers treat students by paying attention to their developmental progress & 2 \\
Total & 2 \\
\hline &
\end{tabular}
$\mathrm{N}=155$

As it appears from Table 1, teacher candidates' positive attitude and behaviours at schools are combined under the subthemes of support, communication skills, education media, and education. In subtheme 1, teacher candidates express that school administration and mentor teachers have helped and supported them during their internship (f: 106); in subtheme 2, they express that Student-teacher communication is good and friendly one (f:28); in subtheme 3, they express that physical and technological opportunities are good at schools of implementation (f: 26); in subtheme 4 for education, they express that students listen to their teacher carefully during class and proactively interact, course planning and presenting are both good (f: 39).Two quotation examples from teacher candidates and mentors' explanations are given below:

Teacher candidates stated, that "in the practice school all teachers helped us in the professional way and supported us" TC4M., TC2F.. Again some mentor teachers said that "they strived to improve themselves in the practice process, to develop professional knowledge" MT39F,MT28M. In total, teacher candidates' positive attitude and behaviours gather at frequency 199. 
Table 2. Teacher candidates positive attitudes and behaviours during the teaching practice

\begin{tabular}{|c|c|}
\hline Sub Themes & $\mathbf{F}$ \\
\hline \multicolumn{2}{|l|}{ Attitudes arising from Students } \\
\hline Negative attitudes due to students' indifference to school uniform & 27 \\
\hline Students ignore the course/teacher lecture and talk with classmates & 26 \\
\hline Students exhibit lack of discipline & 12 \\
\hline Students are reluctant in taking an active part in class & 10 \\
\hline Students are poorly motivated due to future anxiety & 3 \\
\hline Total & 78 \\
\hline Negative attitudes due to students' indifference to school uniform & 27 \\
\hline Students ignore the course/teacher lecture and talk with classmates & 26 \\
\hline Students exhibit lack of discipline & 12 \\
\hline \multicolumn{2}{|l|}{ Attitudes arising from School } \\
\hline Directors and some of the teachers are indifferent to teacher candidates & 9 \\
\hline Missing course materials at school & 8 \\
\hline Lack of security upon entrance to school & 5 \\
\hline A mass of teacher candidates in classroom have negative effects on students & 5 \\
\hline Classrooms are well equipped with smart boards but they are not used during teaching & 5 \\
\hline School canteen is small and personnel do not follow hygiene rules & 4 \\
\hline Total & 36 \\
\hline \multicolumn{2}{|l|}{ Education-related issues } \\
\hline Courses are merely based on knowledge and inefficient & 9 \\
\hline Some of the teachers fail to associate topics with daily life, hence students cannot get motivated & 6 \\
\hline A mass of teacher candidates in classroom make mentor teachers nervous & 4 \\
\hline Some of the teachers are harsh on students & 4 \\
\hline Inability to upskill social affairs, interactions, social rules and similar social skills & 3 \\
\hline Students are indifferent to some non-math courses (history, geography etc.) & 3 \\
\hline Disrespectful attitudes towards teachers & 2 \\
\hline Conventional methods are used for teaching & 2 \\
\hline Administration is rude towards students & 2 \\
\hline Poor educational level at school & 2 \\
\hline Teachers have poor relationships amongst themselves & 2 \\
\hline Total & 39 \\
\hline \multicolumn{2}{|l|}{ Internship-related issues } \\
\hline No information is given about the topics on management and guidance & 7 \\
\hline Students are indifferent to teacher candidates in classroom & 4 \\
\hline Instructors fail to support candidates sufficiently & 4 \\
\hline Internship term is short & 4 \\
\hline Candidates are not welcomed in teachers' lounge during breaks & 2 \\
\hline Some interns curry favour with the mentor teacher & 2 \\
\hline Mentor teachers discriminate against the teacher candidates & 2 \\
\hline Total & 25 \\
\hline
\end{tabular}
$\mathrm{N}=155$

As it appears from Table 2, negative attitudes and behaviours teacher candidate encounter at schools of implementation gather around four sub themes. In subtheme one; stress is on students' indifference to school uniform (f:27), students ignore the course/lectures (f:26), students exhibit lack of discipline (f:12), and students are reluctant in taking an active part during class (f:10). Sub theme two consists of school related issues such as "Directors and some of the teachers are indifferent to teacher candidates" (f: 9); "missing course materials at school" (f: 8). In subtheme three, education-related issues consist of the followings: "Courses are merely based on theoretical knowledge inefficiently" (f:9); "Some of the teachers fail to associate topics with daily life, hence students cannot get motivated" (f: 6); "Internship term is short" (f: 4) etc. In sub theme four, the followings come to the front: "No information is given about the topics on management and guidance" (f: 7); Students are indifferent to teacher candidates during class (f: 4). Below are sample quotations of the teachers' ideas:

Teacher candidates said that "some students were very hyperactive and it was very difficult to adapt them to the classroom" TC136M, TC82F, Another statement was that "casual clothing of students causes problems among students" TC53M, TC39F, TC54M...Another statement; "I could not my excitement while teaching TC66F, TC73M, TC75M... A mentor teacher also said "teacher candidate did not communicate with the students while they were teaching”" MT42F, MT46F.In total, negative attitudes and behaviours of teacher candidates gather at frequency 77 under four the main themes. 
Table 3. Challenges of teacher candidates during teaching

\begin{tabular}{|c|c|}
\hline Sub Themes & f \\
\hline \multicolumn{2}{|l|}{ Difficulty with teaching } \\
\hline Students are reluctant in taking part and do not want to answer & 23 \\
\hline Course is interrupted by students & 16 \\
\hline Failure to suppress the excitement & 15 \\
\hline Bas time management & 9 \\
\hline Difficulty with using the smart board & 11 \\
\hline Difficulty with catching students' attention & 10 \\
\hline Students have poor pre-learning, and poor level & 6 \\
\hline Cannot reduce himself/herself to students' level & 3 \\
\hline Fear of scientific incapacity & 3 \\
\hline When teacher candidate is teaching mentor teacher constantly interrupts the candidate & 2 \\
\hline Not having any difficulties when teaching and adapting quickly & 6 \\
\hline There are students that do not speak Turkish, and this makes teaching difficult & 3 \\
\hline Total & 107 \\
\hline \multicolumn{2}{|l|}{ Programme Challenges } \\
\hline University-school curricula do not match & 8 \\
\hline Failure to learn how to prepare annual, weekly, daily syllabus & 3 \\
\hline Failure to follow annual plan and programme when teaching & 3 \\
\hline Lack of information about e-school applications & 3 \\
\hline Perception that vocational high school programmes are insufficient for achievement on students' part & 2 \\
\hline Having to compact three-weeks programme on a single day & 2 \\
\hline Failure to determine in advance the number of activities on weekly syllabus & 2 \\
\hline Giving multiple choice test-oriented education & 2 \\
\hline Total & 25 \\
\hline \multicolumn{2}{|l|}{ Classroom management } \\
\hline Difficulty with dominating over the classroom at times & 18 \\
\hline Total & 18 \\
\hline
\end{tabular}
$\mathrm{N}=155$

Table 3 emphasizes "challenges teacher candidate encounter during teaching as the main theme. In sub theme one, challenges teacher candidate encounter when teaching are itemised as "Students are reluctant in taking an active part in class" (f: 23), "students interrupt the course" (f: 16), "teacher candidate cannot suppress his/her excitement" (f: 15), "failure of time management" (f:11), and "failure to use the smart board" (f: 9). In sub theme two, "programme challenges have been highlighted.(f.8). Some mentors these are as follows: "failure to prepare annually, weekly, daily syllabus" (f: 3 ), "failure to follow the annual plan during teaching the course" (f: 3) and similar issues. In subtheme three, "teacher candidates have difficulties in achieving dominance over the classroom" (f: 18) is expressed. Quatation samples from the ideas of the teacher candidates and mentor teacher are given below:

Some mentors said that "teacher candidates could not use the course time well" MT16F, MT7F, MT16M. Some teacher candidates said that" the lessons we took in college and the lessons we did in school were not similar. For this reason, I had difficulty teaching" MT23M, MT123M..Another expression; "candidates have difficulty in establishing the class domination" MT34F, MT36F... In subthemes "challenges teacher candidates encounter when teaching at schools gather at frequency 150 under three sub themes. 
Table 4. Opinions of mentor teachers about the teacher candidates

\begin{tabular}{|c|c|}
\hline \multirow{2}{*}{\multicolumn{2}{|c|}{$\begin{array}{l}\text { Sub Themes } \\
\text { Candidates' attitudes and behaviours }\end{array}$}} \\
\hline & \\
\hline Candidates are in general respectful towards, show refined attitudes to and are careful with the teachers. & 38 \\
\hline Candidates are interested in, keen on, curious about the application and make good efforts. & 18 \\
\hline Candidates employ a good wording, and show good attitudes and behaviours. & 9 \\
\hline They are familiar with their tasks and duties. & 6 \\
\hline They come up with excuses at all times and wish to leave early. & 5 \\
\hline Total & 76 \\
\hline \multicolumn{2}{|l|}{ Candidates' attitudes and behaviours to Students } \\
\hline Candidates are particular about the distance when communicating students. & 25 \\
\hline Candidates set a good model by showing good attitudes and behaviours. & 15 \\
\hline They have a loving, tender and respectful approach. & 11 \\
\hline They endeavour to respond to information-seeking questions raised by students. & 6 \\
\hline They try to make observations about students. & 3 \\
\hline Some candidates have redundant approaches to students & 2 \\
\hline Total & 62 \\
\hline \multicolumn{2}{|l|}{ Candidates' difficulty with teaching } \\
\hline Failed time management for the course & 24 \\
\hline Insufficient command over the course, and panic caused by lack of preparations for the course & 13 \\
\hline Failure to control over his or her excitement when teaching & 11 \\
\hline Difficulty with intonation when teaching & 8 \\
\hline Difficulty with planning the course & 7 \\
\hline Difficulty with using smart board & 5 \\
\hline Nervousness due to presence of mentor teacher and teaching fellow in the classroom & 5 \\
\hline Failure to make use of methods and tools suitable for the subject being taught & 4 \\
\hline Complicating the subject by diving into details, and failure to reduce his or her level in tune with that of the students & 4 \\
\hline Failure to teach as planned & 2 \\
\hline Difficulty with responding to students' questions & 2 \\
\hline Failure to associate the subject with prior and subsequent subjects & 2 \\
\hline Unwillingness to take up responsibility & 2 \\
\hline Failure to communicate during teaching & 2 \\
\hline Total & 91 \\
\hline
\end{tabular}

$\mathrm{N}=56$

As it appears from Table 4, mentor teachers' opinions on the teacher candidates have been examined under three sub themes. In the sub theme one, mentor teachers express that teacher candidates 'respectful, refined, kind and careful' (f: 38/), 'willing to, keen on and make good efforts for practice' (f:18), 'have good manners, attitudes and behaviours' (f: 8), 'aware of their tasks and duties (f: 6). As a negative attitude and approach, they express that 'some of the candidates make excuses at all times and want to leave the school early (f: 5). In the subtheme two, it has been highlighted that 'student candidates have established a good communication with students' (f: 25), 'exhibit exemplary attitudes and behaviours' (f: 15), 'act respectfully, loving, caring an understanding' (f: 11), 'they make good efforts to response to students' questions within the framework of education' (f: 6). In the sub theme three, teacher candidates' difficulty with teaching has mostly been related to 'candidates' failure to finish teaching within prescribed term' (f: 24), 'insufficient control over the subject being taught' (f: 13), 'failure to suppress his /her excitement during teaching' (f: 11). In addition, it has been observed that teacher candidates have difficulty with planning the module, using smart board, elaborating and reducing himself/herself to students' levels, failure to have an interactive communication with the students when teaching, some candidates' reluctance in taking up their responsibility, failure to select methods and tools suitable for the topic being taught'.

Some mentor teachers said that "teacher candidates who did not prepare enough for the lessons and therefore they panicked while teaching” MT27F. MT110F, MT119F”Anothar statement; "they couldn't use smartboard effectively to the classroom MT42M, MT36F". Another statement; "Teacher candidates have suffered in the course of planning"MT18F, MT20M, MT32M... In total, teacher's opinion on teacher candidates gather around frequency 229 under three sub themes. 
Table 5. Opinion of coordinators about the teacher candidates

\begin{tabular}{ll}
\hline Sub Themes & f \\
\hline Candidates' attitudes and behaviours & 21 \\
Positive, kind, refined attitudes and behaviours as expected from a teacher & 12 \\
Respect for school, and respectful to teachers and students & 5 \\
Display capacity to overcome professional challenges & 5 \\
As king to learn about teaching as a profession and management & 2 \\
Candidates fulfil a given task & 2 \\
Some candidates are reluctant for internship, and refer to schools that tolerate absence from & $\mathbf{4 7}$ \\
internship & 14 \\
Total & 2 \\
Candidates' attitudes and behaviours towards students & 1 \\
Candidates establish a good dialogue with students, guide them and become friendly & 5 \\
Swarmer students' questions & $\mathbf{2 2}$ \\
opinion that no problem has been experienced with the candidates & 3 \\
Total & 3 \\
Candidates' difficulty with teaching & 3 \\
Difficulty with preparing plans and using methods & 2 \\
Difficulty with using smart board & 2 \\
Failure to finish and conclude within prescribed time & 2 \\
Inexperience & \\
Failure to control his/her excitement when teaching & 2 \\
Failure to control over students when teaching & 2 \\
Failure to put theoretical knowledge into practice & $\mathbf{1 7}$ \\
\hline Total &
\end{tabular}

$\mathrm{N}=16$

As it appears from Table 5, coordinators' opinion on teacher candidates is gathered around three sub-themes. In sub theme one, it has been underlined that teacher candidates have 'positive, kind, refined attitudes and behaviours as expected from a teacher' (f: 21), 'respect for school, and respectful to teachers and students' (f: 12), 'display capacity to overcome professional challenges' (f: 5), all of which relate to general attitude of the candidates. In the sub-theme two, "candidates have established a good dialogue with students, guide them and become friendly' (f: 14) has been striking. In the sub-theme three, a similarity has been noted down between the teacher candidates' difficulty with teaching, and observations made by the coordinators, mentor teachers and teacher candidates in the matter. These are mainly as follows: 'Candidates have difficulty with preparing a course plan and using suitable methods (f: 3 ), have difficulty with using smart board (f: 3 ), have difficulties in controlling over students (f: 2 ), cannot suppress his/her excitement (f: 2), have inexperience (f: 2 ), fail to put theoretical knowledge into practice (f: 2 ).

Generally coordinator school administrators stated that "teacher candidates left a positive impression with their positive attitudes during the implementation period" C 71M, C66F, C110M, C113M.

In total, coordinators gave 86 opinions under three sub themes about the teacher candidates.

\section{Conclusion, Discussion and Recommendation}

According to the results of this research study; teacher candidates, mentor teachers and coordinators are satisfied with pedagogical formation education and practices at schools. Teacher candidates expressed that mentor teachers and coordinators supported and helped them with the implementation process; shared their opinions and experience and guided them with any trouble in controlling over the class.

In some studies, teacher candidates express that teaching implementation process is very useful in general, adding that mentor teachers have been helpful with solving any problems at the school of implementation; that mentor teachers with sufficient qualifications have been influential effects on teacher candidates, whereas mentor teachers with negative attitudes cause disengagement with the profession; and that problems occur due to lack of exchange of opinions and communication between instructors and mentor teachers, and also due to not taking time to study over the school-faculty collaboration guidelines have been experienced every now and then (Azar, 2003; Can, 2001; Eraslan, 2008; Güzel, Berber and Oral, 2010; Kaya and Samanc1, 2013; Köse, 2014; Selçuk and Yeşilyurt, 2007; Sılay and Gök, 2004).

In this study, the candidates have expressed that mentor teachers have sometimes interrupted during the teaching in the classroom, which made them nervous. However Chudleigh and Gates (2010) defined that it is reasonable for a mentor 
teacher to positively interrupt with and support the teacher candidate with his/her own experience when teaching in case the candidate is observed having difficulty with knowledge and contents (Chudleigh and Gates, (2010). Kyl, Moore and Sanders (1999) discussed that mentor teachers are crucial for raising teacher candidate and also for sharing their experience in practice rather than knowledge. They further argue and defined that mentor teachers should exchange information with mentor instructors from universities and faculties through school and region specific works. Hence teachers with experience should be signed as mentor teachers and also supported as professional implementers. Peterson (1996) defined that mentor teachers should be supportive, patient, eager to guide consultants that take care of teacher candidates' improvement and development, and share experience with them.

Findings of the study demonstrate that teacher candidates are happy with the mentor teachers. They hold positive opinions with regards to mentor teachers' planning the course, presentation to students, strict examination terms and students' active participation. However some of the teacher candidates think that the courses they teach differ from what they have studied. In a research by Gündoğdu (1998), Can (2001) and Orhan (2017) it is specified that candidates cannot have sufficient grounds to put into practice what they have studied at their faculty; that the schools did not prepare the candidate for professional life under different conditions; no suitability was enabled in planning and filing all activities.

In this study, some of the negative attitudes and behaviours observed by the teacher candidates at schools of implementation are as follows: Students' indifference to school uniform, students' attempts to disrupt the class and lack of discipline, students' reluctance in participating in the class. School-based problems are referred to as follows: Lack of security upon entrance to school, lack of interest on the part of some directors and mentor teachers, students' lack of motivation because of teaching knowledge-based courses, and conventional teaching techniques.

Teacher candidates experience difficulty mostly with anxiety and excitement especially starting of lectures and adapt to courses afterwards. Candidates also experience problems with failure to make students stay focused on the course, failure to time management, difficulty with using smart board, failure to implement modern methods and techniques, fear of scientific incapacity, failure to reduce himself/herself to students' level, being interrupted by mentor teacher when teaching, lack of sufficient information about e-school practices. In their study, Poulou (2007) and Boz (2008) defined that teacher candidates experience a set of different emotions in the beginning; and that they are more concerned about the profession when teaching their first classes/lectures, adding that their concern diminishes as they proceed with their classes. In their study, Yapıcı and Yapıc1 (2004) specify that teacher candidates do not have sufficient information about the methods of teaching; however their observations of the course relating to their branch have been useful. Orhan (2017) argued that education received by teacher candidates is not sufficient as it does not prepare them or make them qualified for teaching superior intelligence students, classroom management, communication with parents, formal procedures and correspondences, regulations etc., adding that root of the problem is the lack of practices and lack of instructors in programmes. The same problem has also been found out in this study.

In this study, mentor teachers and coordinators express as follows: "Teacher candidates' attitudes and behaviours are fit and proper for teachers, they are respectful and refined towards teachers and students, love practical education, are aware of their tasks, duties and responsibilities, make good efforts to observe and respond to students.' because the collaboration by and between Karabuk University, and Karabuk National Education directorate is well enabled, collaboration between schools is well established, there is a balanced coordination in distribution of student-teacher-instructor, remuneration process is efficient and smoothly operated. When combine, these pave the ground for a yielding results.

Based on this study, followings are the recommended:

It is necessary that teacher candidates' theoretical studies are supported with practical experience and integrated in the educational study programmes. Missing points and deficiencies in teacher raising programmes should be redefined depending on the results of implementation. Teacher candidates should be supported with seminars on how to make effective use of smart boards under Fatih Project. Teacher candidates daily outline syllabus and activities should be monitored by instructors and evaluated periodically. Implementation-oriented meetings, courses and seminars should be held on a yearly basis to enable collaboration between the faculty and school of implementation. In the light of the integrity of embedding, the teacher candidates should follow-up with and participate in the social and cultural events and activities at schools. The results of this study conducted for teacher candidates should be examined to identify and eliminate missing points, teacher candidates should be given the opportunity of gaining experience in the actual process during their formation study. 


\section{Acknowledgements}

This research is financially supported and funded by the following institutions:

1. Karabuk University

2. ICLEL 2017 in Porto/Portugal.

\section{References}

Abazoğlu, İ. (2014). Teacher training programs in the world and professional development practices for teachers. Turkish Studies - International Periodical for the Languages, Literature and History of Turkish or Turkic. Ankara/Turkey, 9(5), 1-46.

Azar, A. (2003). Reflections on view of school experience and teacher practice courses. Milli Egitim Dergisi, 159.

Boz, Y. (2008). Turkish student teachers' concerns about teaching. European Journal of Teacher Education, 31(4), 367-377. https://doi.org/10.1080/02619760802420693

Can, N. (2001). Problem faced by the reorganization of the management of teaching practice. Erciyes Üniversitesi Sosyal Bilimler Enstitüsü Dergisi, 11, 1-16.

Chudleigh, A. M., \& Gates, C. G. (2010). Supporting teacher candidates At-risk in field experiences: Organizational and program responsiveness. Initial Teacher Education Program. 02.08. 2017 tarihinde https://www.oise.utoronto.ca/ite/.../File/SupportingTCs.pd adresinden erişildi

Darling-Hammond, L. (2006). Consricting 21st-Century teacher education. Journal of Teacher Education. 24.07.2017 tarihinde jte.sagepub.com/content/57/3/300.short adresinden erişildi

Darling-Hammond, L., Hammerness, K., \& Shulman, L. (2005). The design of teacher education programs. Chapter eleven. In preparing teachers for a changing world. What teachers should learn ad be able to do. Edited by L.D. Hammond and J. Bransford.Wiley Jossey Bass Inc. San Francisco.

Eraslan, A. (2008). Faculty school collaboration program. Mathematics teacher candidates view on school practice courses. Hacettepe Üniversitesi Ĕ̆itim Fakültesi Dergisi (Hacettepe University, Journal of Education), 34, 95-105.

Gündoğdu, K. (1998). Teaching practice studies an point of view from Agrı Education Faculty with the Agrı province practice schools. VII. Ulusal Egitim Bilimleri Kongresi (9-11 Eylül 1998). Konya: Selcuk Universitesi Egitim Fakultesi Yayınları, Cilt I, 497-502.

Gürlen, N. E., \& Demirel, Ö. (2010). The comparative analysis of teacher competencies in the European Unions and Turkey. Proceedings of International Conference on Teacher Training Policies and Problems II, 396-401.

Güzel, H., Berber, N. C., \& Oral, İ. (2010). Teachers' and Lectures' view on teaching practice in the co-operation program of the school of education. Kastamonu Egitim Dergisi, 18(1), 19-36.

Karasar, N. (2005). Bilimsel Araştırma Yontemi, kavramlar-ilkeler-teknikler. Scientific Research Methods, concepts, principles, techniques. Ankara: Nobel.

Kavak, Y. (1999). A new approach in teacher staft attitudes towards school experience and teaching practice courses. Kuram ve Uygulamada Egitim Yönetimi.Yaz 1999.

Kaya, H. Ş., \& Samanc1, O. (2013). First impressions of classroom teacher candidate about the communication during the teaching process. AKEV Akademi Dergisi, 1(1), 419-428.

Köse, E. Ö. (2014). Student and teacher-staff attitudes towards school experience and teaching practice courses (Erzurum example). Dicle Üniversitesi Ziya Gökalp Eğitim Fakültesi Dergisi, 22, 1-17

Kyle, D. W., Moore, G. H., \& Sanders, J. L. (1999). The role of the mentor teacher: İnsight challenges, and implications. Peabody Journal of Education, 74(3-4), 109-122. https://doi.org/10.1080/0161956X.1999.9695376

MEB (1998). Instruction on teaching practice to be done in the education and training institutions affiliated to the Ministry of National Education. Tebligler Dergisi. Ekim1998/2493, Cilt: 6

MEB (2009). Ogretmenlik mesleği genel yeterlikleri. From otmg.meb.gov.tr/belgeler/Yeterlikler.doc (retrived on 12 July 2016).

MEB. (1994). Turkish National Ministry of Education Development Project (TU-3192). From, www.meb.gov.tr/earged/earged/Milli_Egitimi_Gelistirme(retrived on 10 may 2017).

Orhan, E. E. (2017). What does he think about the teacher candidates the training they received in Turkey? A qualitative research. Egitim ve Bilim, s.189, 197-216. 
Patton, M. Q. (1987). How to use qualitative methods in evaluation, program evaluation kit. California: Sage Publications

Peterson, R. (1996). What is a mentor? From http://www.gse.uci.edu/doehome/EdResource/Publications/MentorTeacher/Contents.html (retrived on 10 July 2016)

Poulou, M. (2007). Student teachers' concerns about teaching practice. European Journal of Teacher Education, 30 (1), 91-110. https://doi.org/10.1080/02619760600944993

Rubin, H. J., \& Rubin, I. S. (2005). Qualitative interviewing. The art of hearing data. Sage Publication, Thousand Oaks, London, Newyork. https://doi.org/10.4135/9781452226651

Sarıtaş, M. (2007). Evaluation of opinion about the benefits of the teachers' school experience practice to teacher candidates.Uludag Universitesi Egitim Fakultesi Dergisi, 20(1), 121-143.

Selçuk, A., \& Yeşilyurt, M. (2007). The teacher candidates' school experience-2 "s opinions on the lessons "Yüzüncü Y1l Universitesi Örnegi. Yuzuncu Yll Universitesi Egitim Fakultesi Dergisi. Aralık 2007, 48(2), 75-90.

Sılay, İ., \& Gök, T. (2004). Teacher candidates' application problems they encounter in their schools and prepared a study on suggestions to resolve these issues, XIII. Ulusal Egitim Bilimleri Kurultayl, 6-9 Tеттиz. 2004, Inonu Universitesi, Egitim Fakultesi, Malatya.

Yapıcı, S.., \&Yapıcı, M. (2004). Teachers 'opinions regarding the candidates' school experience-one lessons. İlkogretim Online, 3(2), 54-59.

Yıldırım, A., \& Şimşek, H. (2008). Sosyal Bilimlerde Nitel Arastırma Metodları.7.Baskı.Seckin: Ankara.

YOK (1982). Higher Education Law. Resmi Gazete.Tarih: 6/11/1981, 17506.

YOK. (2007). Turkey's Higher Education Strategy. Subat, 2007. Yuksekogretim Kurulu Yayını. Ankara.

\section{Copyrights}

Copyright for this article is retained by the author(s), with first publication rights granted to the journal.

This is an open-access article distributed under the terms and conditions of the Creative Commons Attribution license which permits unrestricted use, distribution, and reproduction in any medium, provided the original work is properly cited. 